\title{
More than a Fair Share? Principal-Principal Conflicts in Emerging Markets: Evidence from India
}

\author{
Radha M. Ladkani ${ }^{1} \&$ Ashok Banerjee ${ }^{2}$ \\ ${ }^{1}$ Indian Institute of Management Indore, Indore, India \\ ${ }^{2}$ Indian Institute of Management Calcutta, Kolkata, India \\ Correspondence: Radha M. Ladkani, Indian Institute of Management Indore, J-205, Faculty Block-J, \\ Rau-Pithampur Road, Rau, Indore, Pin-453331, India. Tel. 91-731-243-9698. E-mail: radhal@iimidr.ac.in
}

Received: March 28, 2016

Accepted: May 6, 2016

Online Published: June 25, 2016

doi:10.5539/ijef.v8n7p31

URL: http://dx.doi.org/10.5539/ijef.v8n7p31

\begin{abstract}
The concentrated ownership structure of emerging market firms may help mitigate principal-agent conflicts; however, the presence of two sets of principals, promoters with controlling stake and dispersed shareholders, may give rise to principal-principal conflicts. India, where firms are largely organized as business groups, with stock pyramids and complex cross-ownership structures, presents a distinctive venue to study the presence of such conflicts. This paper tests if the principal-principal conflicts transpire in the form of risk aversion when Indian bidders seek to merge or acquire. We observe that Indian bidders resort to risk-aversion only when promoters have high cash flow rights, that is, when they hold a majority stake in the acquiring firm. We argue that in business group firms this is likely to happen due to 'tunnelling distortion', whereas in standalone firms, this is likely to occur due to 'portfolio concentration'. However, on investigating deal-announcement returns, we observe that firms with high promoter ownership create value.
\end{abstract}

Keywords: principal-principal conflicts, agency theory, India, M\&A, ownership concentration, promoter-manager, risk-taking behaviour

\section{Introduction}

The classic agency-theory that stems from the disharmony of interests and goals of principals and agents (Jensen \& Meckling, 1976) is well suited to address corporate governance concerns in the countries where the stock-ownership is dispersed. However, business settings where the high concentration of ownership is predominant, call for addressing governance issues through the lens of principal-principal conflicts (Young, Peng, Ahlstrom, Bruton, \& Jiang, 2008).

In emerging markets, factors like concentrated and complex ownership structures, weak shareholder protection, and institutional voids, give rise to conflicts between the majority and minority shareholders (Young et al., 2008). India presents a unique venue to test the presence of such conflicts. In Indian firms, promoters have high ownership stakes, and also control the management of the firm (we label them promoter-managers). Furthermore, the pyramidal-stock ownership structure (Note 1) enables promoters to have greater control compared to their cash flow rights in a lower level business group firm as well (Khanna \& Palepu, 2000a). As a consequence of this phenomenon, two sets of shareholders emerge. One set of shareholders are the promoter-managers, whereas, the other set of shareholders have a substantial yet minority stake in the firm, but are widely dispersed to have any significant say in management's decisions. In such a setting, there is a greater possibility for the promoter-managers to ignore the interests of the minority shareholders, which could give rise to principal-principals conflicts (Dharwadkar, George, \& Brandes, 2000; Morck, Wolfenzon, \& Yeung, 2005).

The classical agency literature assumes that managers are opportunistic; and there is extant empirical evidence that suggests that the managers have a tendency to make suboptimal risk choices (entrenchment hypothesis, Shleifer \& Vishny, 1989). A widely acknowledged reason is the non-diversifiable employment risk faced by a manager (Amihud \& Lev, 1981). Besides, making risky investments can also limit a manager's rent seeking ability (perquisite consumption) since it requires more prudent use of the firm's resources (Jensen, 1986, 1993). Such managerial opportunism is addressed by effective incentive design and compensation structure that includes equity and option holdings (based on the incentive alignment hypothesis). This approach is based on the 
premise that high equity ownership of managers can help mitigate the risk-avoidance resorted to, by them. Now, since, most of the Indian firms already have promoter-managers (Note 2), that is, managers with high equity stakes, we believe it would be interesting to study if their risk-related behaviour favours all the shareholders including the dispersed shareholders, when they make external corporate investment decisions, or they resort to risk aversion in the same fashion as their western counterparts.

In this paper, we test if the principal-principal conflicts transpire in the form of risk aversion when Indian bidders seek to merge or acquire. Therefore, we assess the risk-taking behaviour of bidders in an emerging market, i.e. India. We observe that Indian bidders are undertaking value enhancing risky deals as long as the promoters do not hold majority stake (i.e., more than 50 per cent shares). The Indian bidders resort to risk-aversion when promoters hold majority stake, that is, when their cash-flow rights in a firm are more than fifty per cent. We posit that in business group firms this is likely to happen due to 'tunnelling distortion' whereas in standalone firms, this is likely to occur due to 'portfolio concentration'. However, on investigating the announcement returns of such deals, we observe that on an average the managers (promoter-managers) do not destroy value.

The paper is organized as follows: the next section presents the literature review and research objective; the third section presents the methodology; the fourth section presents the data and the sample selection; the fifth section presents the results and a brief discussion, and the sixth section presents our concluding remarks.

\section{Literature Review and Research Objective}

For our study, we have borrowed heavily from the literature on managerial opportunism, which addresses the concerns of the traditional agency problem observed in developed countries with dispersed ownership. But, we attempt to extend the new branch of agency theory literature which considers the conflict of interest between the majority and the minority shareholders (Dharwadkar et al., 2000), and is more relevant in the context of the emerging economies where high ownership concentration among the promoters is a classic feature of firm ownership (Young et al., 2008). In this study, we test the presence of principal-principal conflicts in India by employing the established empirical approaches used to study the traditional agency problems in developed countries, and hence we review this literature at length. A study similar to ours yet quite different in context is undertaken by Chen and Young (2010), who have found empirical evidence supporting the principal-principal agency concerns in Chinese state owned enterprises.

In their seminal work, Amihud and Lev (1981) consider the impact of managerial ownership on the firm diversification activity and propose the 'employment risk' argument to explain managerial risk-aversion. They suggest that since a manager's income is dependent on firm's performance, and she bears the non-diversifiable risk of losing her job, she is induced to reduce this risk by entering into conglomerate mergers.

Literature on managerial opportunism offers several behavioural explanations like the 'empire building' motivation (Jensen, 1986, 1993) and the 'hubris' hypothesis (Roll, 1986), which also help us understand why managers' act against their shareholders by making value-destroying decisions. Managers driven by empire building motivations like to have greater control over the firm's resources to derive larger private benefits, whereas, managers guided by their overconfidence (hubris) tend to make valuation mistakes.

The empirical literature in this area primarily explores the relationship between equity ownership, including stock option grants and other components of executive compensation, and managerial opportunistic behaviour (including entrenchment). Empirical studies by Lloyd, Modani, and Hand (1987), Morck, Shleifer, and Vishny (1990), and Saunders, Strock and Travlos (1990), support Amihud and Lev's (1981) conclusions. They observe that manager-controlled firms are more prone to diversifying their income streams, which implies risk-averse behaviour on the part of the managers. But Lane, Cannella, and Lubatkin, (1998) present contradictory evidence advocating that managers do not always exhibit risk aversion. In fact, they propose stewardship theory in support of managers' behaviour with respect to mergers and acquisitions. Similarly, Rose and Shepard (1997) show that due to the challenges and demands of the job that the CEOs of diversified firms are able to fetch greater salaries and bonuses than their counterparts in non-diversified firms, and not due to the entrenchment reasons. However, a more recent study by Shekhar and Torbey (2005) found evidence hinting managerial-opportunism in Australian M\&A. They found that increased equity ownership leads to greater diversification; nevertheless, such diversification deals are not value destroying.

A strand of empirical literature on managerial opportunism explores the relationship between equity ownership and firm value. McConnell and Servaes (1990) observe a non-linear link between equity ownership by corporate insiders and firm value, with inflection point at the 40-50 per cent ownership level. A similar positive link is observed in Frye (2004), but Sesil, Kroumova, Kruse, and Blasi (2007) conclude such a link only in favour of stock options. 
Another strand of literature uses M\&A deal announcement abnormal returns as a tool to investigate managerial opportunism. Lewellen, Loderer, and Rosenfeld (1985) report higher abnormal returns on merger announcements for firms with higher insider (managerial) ownership, thus, implying that agency conflicts are reduced by increasing management's equity ownership. Cornett, Hovakimian, Palia, and Tehranian (2003) observe the negative investor reaction around diversification deal announcements by acquiring banks, thus, implying that agency concerns are not completely addressed through corporate governance mechanisms like equity \& option holdings; however, Minnick, Unal, and Yang (2011) observe contradictory results for small \& medium sized banks.

A considerable stream of literature on managerial opportunism investigates the risk taking behaviour of insiders (i.e. managers) given their equity ownership and/or compensation structure. Agrawal and Mandelker (1987) observe a positive relationship between the extent of stock \& options held by the managers \& their risk taking behaviour, but Lewellen, Loderer, and Rosenfeld (1989) find very weak evidence in support of this view.

The aforementioned discussion suggests that the literature in this area has evolved over the years but the final word is yet to be said. There are conflicting evidences with regards to equity and option ownership by the insiders/managers/executives and its impact on firm's long term growth strategies like acquisitions (related or unrelated) and idiosyncratic risk. Moreover, over time the authors have considered different components of executive compensation, board structure, presence of block holders and other corporate governance mechanisms to study the dynamics of managerial risk taking.

High promoter ownership in Indian companies makes it a classic case to study the above inter-linkages from the perspective of principal-principal agency. In the light of the above discussion, we undertake this study to test if we observe managerial opportunism in the form of principal-principal agency in Indian companies when they make external corporate investment decisions. Firstly, we address this inquiry by analysing the impact of high ownership concentration on the risk-taking behaviour of its management, i.e., we test if M\&A deals by highly concentrated bidders lead to decrease in post-deal risk (idiosyncratic). Subsequently, we study the acquisitiveness (M\&A activity) of highly concentrated bidders. Our objective is to test the impact of promoter holdings on their M\&A activity. M\&A activity is another proxy for risk, and it mirrors the idiosyncratic risk proxy. And thirdly, we study if the firms with potential for the presence of principal-principal conflicts make value-creating or value-destroying acquisitions.

\section{Methodology: Risk Taking Behaviour of the Bidders: Tobit and Negative Binomial Regression}

To study the promoters, or managers, risk taking behaviour, we consider the ratio of post-deal risk over the pre-deal risk (Lewellen et al., 1989, Williams \& Rao, 2006). Since our dependent variable is the standard deviation of security returns (absolute and market-adjusted), the value of this measure cannot go below zero, that is, the response variable is bounded on the lower side. Hence, based on the characteristic of our dependent variable, the model that we test is a corner-solution model, and the use of the ordinary least square regression would not be appropriate, since it can give us negative predictions. Thus, we employ tobit regression analysis, which is a hybrid of the OLS regression and the probit regression analysis (Note 3).

$$
\text { Post }- \text { deal Risk over Pre }- \text { deal Risk } k_{i}=\alpha+\beta_{1} \text { Insider Own } n_{i}+
$$

$\beta_{2}$ Insider OwnOnsider rscrease in post vior.ion, atio of director'o use the ratio of and thesis concerning the presence of prinicpal -

$$
\operatorname{ter}_{i}^{2}+\beta_{3} \text { Rel_FF }_{i}+\beta_{4} \text { Controls }_{i} \text { (eg.Log Deal Size,_Acq_Percent,DE,BG,Post_1991,industry effects,year effects) }
$$

For the pre-deal period risk calculation, we calculate the risk variable over a period of 180 days starting 30 days before a deal, and for the post-deal risk calculation, we measure risk variable over a 180 day period starting 11 days after the completion of a deal (Williams \& Rao, 2006).

Insider $\mathrm{Own}_{i}$ is the proxy for promoter holdings. We have used two proxies of insider owners in our analysis on the idiosyncratic risk, and six proxies of the same variable in our analysis on M\&A Activity. We have also employed a squared variable of each of the insider ownership proxies because this variable is likely to have a curvilinear relationship with the risk measure. This curvilinear relationship is suitably captured by introducing a squared term of the insider ownership measure.

We also employ another model to test the risk taking behaviour of insider owners. In this model, we employ the number of M\&A deals, termed as M\&A activity (overall, and only diversification only, i.e., deals in unrelated industries), by bidders in ten years prior to a given deal announcement as the dependent variable. The response variable in this model is a count variable, and hence we employ negative binomial regression analysis to estimate the following model: 


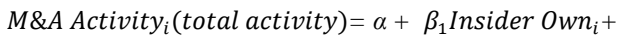

$\beta_{2}$ Insider OwnOnsider rscrease in post vior. ion, atio of director'o use the ratio of and thesis concerning the presence of prinicpal $\operatorname{ter}_{i}^{2}+\beta_{3}$ Rel_FF $_{i}+\beta_{4}$ Controls $_{i}$ (eg.Log Assets, DE, Post_1991, industry effects, year effects.)

$M \&$ Activity $_{i}$ (in unrelated ind. $)=\alpha+\beta_{1}$ Insider iwn $_{i}+$

$\beta_{2}$ Insider OwnOnsider rscrease in post vior. ion, atio of director'o use the ratio of and thesis concerning the presence of prinicpal -

$$
\text { ter }_{i}^{2}+\beta_{3} \text { Rel_FF }_{i}+\beta_{4} \text { Controls }_{i} \text { (eg. Log Assets, DE, Post_1991, industry effects, year effects.) }
$$

The dependent variable in models 2 and 3 is the mirror image of the risk proxy used in the model no. 1 . In these models ( 2 and 3 ), the increase in the dependent variable would suggest risk aversion, whereas, an increase in the dependent variable of model 1, would suggest greater risk taking. We have kept all the independent variables in the model 1, 2 and 3 as the same; however, we have deleted some of the control variables not relevant for M\&A activity models (model no. 2 and 3 ).

Table 1. Statistical properties of key variables (used for risk analysis)

\begin{tabular}{|c|c|c|c|c|c|c|c|c|}
\hline Variable & $\mathrm{N}$ & Mean & Median & Stdev & Max & Min & Q1 & Q3 \\
\hline Var Ratio & 224 & 1.0179 & 0.9687 & 0.4043 & 2.8801 & 0.1307 & 0.7262 & 1.2722 \\
\hline Mkt. Adj. Var Ratio & 224 & 0.9802 & 0.9737 & 0.1763 & 1.5255 & 0.3495 & 0.8719 & 1.1011 \\
\hline Deal Value & 224 & 83.292 & 12.708 & 226.646 & 1691.064 & 0.002 & 3.774 & 43.862 \\
\hline Percent Acq & 224 & 0.6582 & 0.6767 & 0.3176 & 1.0000 & 0.1000 & 0.3925 & 1.0000 \\
\hline Percent Owned & 224 & 0.7637 & 0.9107 & 0.2791 & 1.0000 & 0.1000 & 0.5105 & 1.0000 \\
\hline Insider Own Proxy1 & 224 & 0.4712 & 0.4625 & 0.1887 & 0.8950 & 0.0000 & 0.3419 & 0.6144 \\
\hline Insider Own Proxy2 & 224 & 0.4544 & 0.4522 & 0.2000 & 0.8950 & 0.0000 & 0.3182 & 0.6099 \\
\hline Insider Own Proxy3 & 224 & 0.4017 & 0.3977 & 0.2167 & 0.8950 & 0.0000 & 0.2628 & 0.5406 \\
\hline Insider Own Proxy4 & 224 & 0.6828 & 0.7016 & 0.1701 & 0.9783 & 0.0412 & 0.5714 & 0.8035 \\
\hline Insider Own Proxy5 & 224 & 0.5734 & 0.5745 & 0.1817 & 0.9655 & 0.0369 & 0.4612 & 0.7000 \\
\hline Insider Own Proxy6 & 224 & 0.3283 & 0.3377 & 0.2463 & 0.8950 & 0.0000 & 0.0797 & 0.5005 \\
\hline Debt & 203 & 20390.04 & 2134.30 & 72740.16 & 739044.80 & 0.50 & 595.90 & 9810.90 \\
\hline $\mathrm{DE}$ & 224 & 0.7021 & 0.5000 & 0.9540 & 10.2200 & 0.0000 & 0.1150 & 0.9500 \\
\hline Debt_cost & 214 & 0.0897 & 0.0755 & 0.0839 & 0.6718 & 0.0000 & 0.0469 & 0.1057 \\
\hline
\end{tabular}

Note. This table presents summary statistics of key variables used in the Risk analysis using regression model. The definitions of the variables are presented in Appendix A.

\subsection{Variability in Returns as a Measure of Risk}

In this study, we consider variability in bidder's stock returns as one of the measures of risk. We employ two different measures of risk, a. raw standard deviation of stock returns, and b. market adjusted standard deviation of stock returns. The first measure is the overall variability in stock returns, whereas the second measure, that is, the residual standard deviation of returns (market adjusted standard deviation of returns), represents an estimate of the firm's unsystematic risk. Lewellen et al. (1989) and Williams and Rao (2006) have employed these measures of risk to study the impact of management's stock ownership and options holdings on firm risk.

\subsection{M\&A Activity as a Measure of Risk}

Amihud and Lev (1981) have looked at M\&A activity of bidders to assess the managerial motive for conglomerate mergers. Thus, borrowing from their paper, we have used M\&A activity, that is, the number of M\&A deals by a bidder in ten years prior to a given deal, as another proxy for risk. We have also considered M\&A deals by a bidder only in unrelated industries. Increased M\&A deals suggest risk-reduction behaviour on part of the manager, and vice versa. To capture this measure we have excluded those deals where only assets were acquired. We have also excluded the deals where the percentage of stake acquired was less than ten.

In Table 1B, we have presented a summary of total deals undertaken by Indian acquirers classified as per insider-ownership bucket they belong to. This table clearly shows that M\&A activity, overall and unrelated, is high at lower insider ownership levels, but decreases when the ownership of promoters is more than 25 per cent. This observation suggests that the classical agency problem, the principal-agent problem is mitigated by increasing insider ownership. However, when this insider ownership is more than 50 per cent, the table suggests that there is a slight increase in M\&A activity, indicating the presence of principal-principal conflict. We substantiate this claim by undertaking the negative binomial regression analysis, and the results are discussed in section 5 . 
Table 1B. M\&A Activity as per different insider ownership buckets

\begin{tabular}{lrrrr}
\hline & \multicolumn{3}{c}{ Insider Ownership (Proxy1) } \\
\cline { 2 - 5 } \multicolumn{1}{c}{ M\&A activity in 10 years } & Less than 10\% & 10\% to 25\% & 25\% to 50\% & Greater than 50\% \\
\hline Sum of No. of deals & 36 & 26 & 104 & 111 \\
Average of No. of deals & 5.14 & 2.17 & 0.95 & 1.17 \\
Sum of No. of Unrelated Deals & 22 & 19 & 44 & 52 \\
Average of No. of Unrelated Deals & 3.14 & 1.58 & 0.40 & 0.55 \\
\hline
\end{tabular}

Note. This table presents the total and the average of M\&A activity undertaken by all the Indian acquirers in our sample, classified as per different Insider Ownership buckets. Our objective is to observe the M\&A activity by acquirers falling in certain Insider-Ownership bucket, and also to see if with increase / decrease in insider-ownership, the acquisitiveness of acquirers varies. M\&A activity is the number of M\&A deals by an acquirer in 10 year prior to a deal announcement.

\subsection{Insider Ownership}

Insider Own Proxy1, captures the total promoter holdings, including holdings by persons acting in concert as promoters. Insider Own Proxy2, represents the sum of holdings by all the Promoters, Indian as well as foreign. Insider Own Proxy3, captures the total of Indian Promoters and persons acting in concert as promoters. Insider Own Proxy4, captures holdings by promoters as well as non-promoter institutions like mutual funds, UTI (Unit Trust of India), insurance companies, etc. Insider Own Proxy 5 captures the total percentage of Promoters and non-promoter FIIs' holdings. Insider Own Proxy6 captures the sum of holdings by Indian promoters. Thus, we employ different combinations of promoter and non-promoter holdings to capture the insider ownership effect.

\subsection{Industry Relatedness}

Corporate diversification is the diversification of the firm specific risk, also called the idiosyncratic or the unsystematic risk. As per modern portfolio theory, the unsystematic risk can be managed by the way of diversification and hence should not reflect in the investor's valuation of a firm, however, corporate strategy research differs on this conclusion. In the words of Bettis (1983), 'Modern financial theory suggests that the equity markets will not reward unsystematic risk management, but unsystematic risk management lies at the heart of strategic management'. Thus, Bettis (1983) has put forward an important conundrum faced by academic researchers in the area of modern financial theory and corporate strategy. The empirical research in these fields is yet to agree on a common conclusion, since some research supports the diversification discount hypothesis (Rajan, Servaes, \& Zingales, 2000; Laeven \& Levine, 2007), whereas other body of work suggests that diversification creates value (Villalonga, 2004; ref. Martin \& Sayrak, 2003), for a detailed review of the literature on this issue).

We employ a dummy variable on industry relatedness to separate diversification deals from the deals in the related industries. The diversification research has presented different ways of identifying related and unrelated deals; the most common approach is the use of SIC codes. Researchers have looked at the first two, the first three or the first four digits of the SIC to identify a diversification deal. We did employ this technique of identifying the diversification deals by considering the first three digits of the SIC, but found the industry sector segregation as provided Fama-French was a more reliable indicator of the relatedness of a deal. Thus, based on the Fama-French forty-nine industry classification, if the deals are in different industries, then the dummy value of relatedness for the risk analysis part (tobit regressions) is one.

\subsection{Age Group}

There are five age groups of companies reported on prowess based on the year of incorporation of the firm: a. before 1950, b. between 1951 and 1971, c. between 1972 and 1985, d. between 1986 and 1990, and e. after 1991. Each group represents a different economic environment with respect to industrial licensing, stringency of controls over growth in size, economic reforms, etc. (Note 4). Academic research has shown younger firms are greater risk-takers than the older firms (Fink et al., 2004). Thus, we have considered the 'after-1991' age group category provided by prowess as an independent variable to identify younger firms.

\subsection{Other Controls}

Leverage: We have used debt-equity ratio as one of the control variables, since it is an important determinant of stock return volatility (Guay, 1999). Increase in leverage leads to increase in risk. We have used the square root of the debt-equity ratio of the acquirer, since this transformation helps us make the variable more normally distributed. 
$B G$ : Business Group (BG) affiliation is a significant factor unique to emerging economies, and to capture the effect of this factor on the risk taking behaviour of its affiliates we employ a dummy variable to identify the business group affiliated firms in our model.

Industry Controls: We have used control variables to isolate industry effects on the risk-taking behaviour of bidders. We have controlled for three relevant industries, namely, a. Construction material, building/construction and engineering, b. IT consulting and services, and software, and c. oil and gas, petrochemicals, power and other energy and power.

Year Effects: We have controlled for 2008 and 2009, because after 2007 there was a sharp drop in M\&A activity in India due to the global economic downturn.

\subsection{Measuring Abnormal Returns}

For studying the announcement effects of deals done by firms with high promoter holdings versus the firms with low promoter holdings, we use the event study methodology (Brown \& Warner, 1985; MacKinlay, 1997). We use the market model to estimate the returns, and observe the difference between the actual return and the expected return as the abnormal return. We capture these abnormal returns over different event windows. The market model that is estimated over 200 days is:

$$
E\left(R_{i t}\right)=\alpha+\beta R_{m t}
$$

The abnormal return is captured as:

$$
A R_{i t}=R_{i t}-E\left(R_{i t}\right)
$$

The abnormal return is then aggregated over different event window, where $\mathrm{T}$ represents the length of the window:

$$
C A R_{i}^{T}=\sum_{t=t_{1}}^{t_{n}} A R_{i t}
$$

The $E\left(R_{i t}\right)$ is the expected return from the market model for a bidder I, and $R_{m t}$ is the return on market portfolio for day t. $R_{i t}$ is the actual return of the bidder i for time t. $A R_{i t}$ is the abnormal return for the event $\mathrm{i}$ on the day t. $C A R_{i}^{T}$ is the cumulative abnormal return for the event window $\mathrm{T}$, from day $\mathrm{t}_{1}$ to $\mathrm{t}_{\mathrm{n}}$.

\section{Data}

Our data set comprises mergers and acquisition deals by Indian acquirers from 2001 to 2010. The data on mergers and acquisition deals in India and also the stock price data (for the event study) are taken from Thomson Reuters' Thomson One database. We have taken bidder's company financial information from the CMIE's

\begin{tabular}{|c|c|c|c|c|c|c|c|c|c|c|}
\hline Variables & Var Ratio & $\begin{array}{l}\text { Mkt. A } \\
\text { Var Ratio }\end{array}$ & $\begin{array}{l}\text { Deal } \\
\text { Value }\end{array}$ & Acq_percent & $\begin{array}{l}\text { Percent } \\
\text { Own }\end{array}$ & $\begin{array}{l}\text { Insider } \\
\text { Proxy1 }\end{array}$ & $\begin{array}{l}\text { Executive } \\
\text { Director Comp }\end{array}$ & $\begin{array}{l}\text { Manag-erial } \\
\text { Comp }\end{array}$ & Debt & DE \\
\hline $\begin{array}{l}\text { Mkt. Adj. Var } \\
\text { Ratio }\end{array}$ & $\begin{array}{l}0.92 \\
(0.00)\end{array}$ & 1 & & & & & & & & \\
\hline Deal Value & $\begin{array}{l}0.12 \\
(0.07)\end{array}$ & $\begin{array}{l}0.09 \\
(0.16)\end{array}$ & 1 & & & & & & & \\
\hline Acq_percent & $\begin{array}{l}-0.04 \\
(0.52)\end{array}$ & $\begin{array}{l}-0.06 \\
(0.35)\end{array}$ & $\begin{array}{l}-0.09 \\
(0.19)\end{array}$ & 1 & & & & & & \\
\hline Percent Own & $\begin{array}{l}-0.06 \\
(0.40)\end{array}$ & $\begin{array}{l}-0.06 \\
(0.37)\end{array}$ & $\begin{array}{l}-0.02 \\
(0.71)\end{array}$ & $\begin{array}{l}0.73 \\
(0.00)\end{array}$ & 1 & & & & & \\
\hline $\begin{array}{l}\text { Insider Own } \\
\text { Proxy1 }\end{array}$ & $\begin{array}{l}0.07 \\
(0.31)\end{array}$ & $\begin{array}{l}0.11 \\
(0.09)\end{array}$ & $\begin{array}{l}0.16 \\
(0.02)\end{array}$ & $\begin{array}{l}0.09 \\
(0.20)\end{array}$ & $\begin{array}{l}-0.03 \\
(0.61)\end{array}$ & 1 & & & & \\
\hline Exec. Director & 0.01 & 0.01 & 0.37 & -0.11 & -0.02 & 0.08 & 1 & & & \\
\hline Compensation & $(0.93)$ & $(0.86)$ & $(0.00)$ & (0.19) & $(0.82)$ & $(0.31)$ & & & & \\
\hline $\begin{array}{c}\text { Managerial } \\
\text { Compensation }\end{array}$ & $\begin{array}{l}-0.04 \\
(0.58)\end{array}$ & $\begin{array}{l}-0.04 \\
(0.61)\end{array}$ & $\begin{array}{l}0.35 \\
(0.00)\end{array}$ & $\begin{array}{l}-0.12 \\
(0.09)\end{array}$ & $\begin{array}{l}0.00 \\
(0.98)\end{array}$ & $\begin{array}{l}0.02 \\
(0.82)\end{array}$ & $\begin{array}{l}0.98 \\
(0.00)\end{array}$ & 1 & & \\
\hline Debt & $\begin{array}{l}-0.05 \\
(0.50)\end{array}$ & $\begin{array}{l}-0.05 \\
(0.48)\end{array}$ & $\begin{array}{l}0.56 \\
(0.00)\end{array}$ & $\begin{array}{l}-0.20 \\
(0.00)\end{array}$ & $\begin{array}{l}-0.01 \\
(0.90)\end{array}$ & $\begin{array}{l}0.15 \\
(0.03)\end{array}$ & $\begin{array}{l}0.45 \\
(0.00)\end{array}$ & $\begin{array}{l}0.42 \\
(0.00)\end{array}$ & 1 & \\
\hline $\mathrm{DE}$ & $\begin{array}{l}0.05 \\
(0.44)\end{array}$ & $\begin{array}{l}0.05 \\
(0.42)\end{array}$ & $\begin{array}{l}-0.01 \\
(0.91)\end{array}$ & $\begin{array}{l}0.06 \\
(0.38)\end{array}$ & $\begin{array}{l}-0.01 \\
(0.88)\end{array}$ & $\begin{array}{l}0.07 \\
(0.32)\end{array}$ & $\begin{array}{l}-0.03 \\
(0.72)\end{array}$ & $\begin{array}{l}-0.05 \\
(0.50)\end{array}$ & $\begin{array}{l}0.03 \\
(0.71)\end{array}$ & 1 \\
\hline
\end{tabular}
Prowess (Note 5) database.

Table 2. Pairwise correlation coefficients of key variables

Note. This table reports pairwise correlation coefficients of key variables used for Risk Analysis. p-values are reported in the parenthesis. 
For our study, we have considered deals done by Indian acquirers; so, these deals are domestic and cross border as well. We have filtered only the completed deals; hence the deals that were announced but were terminated, are out of the purview of our study.

We exclude the following types of deals: the acquisition of assets, buybacks, bankruptcy acquisitions, and divestiture. We also exclude those deals where acquirer is an investor group, deals where the value of the transaction is undisclosed or unavailable, deals by private firms, government owned enterprises and by financial firms.

There are deals that are announced in parts, i.e., the deals where the acquirer and the target is same, but the deal value and other deal characteristics differ. In such cases of multiple announcements, we have included the deal with the highest percentage acquired. We have filtered out the deals where the percentage acquired is less than ten. However, to be included in our data set, a deal must have all the required data with respect to closing stock prices and other financial variables used in the study.

\section{Results and Discussion}

A large number of Indian businesses are organized as business groups as a consequence of India's business history and the institutional voids that are generally observed in the emerging markets (Khanna \& Palepu, 2000b). Most of these business groups are family owned with high promoter holdings, as a classic feature of their ownership structure (Huchet \& Ruet, 2006). On one hand, there is a likelihood of tunnelling in business groups (Bertrand, Mehta, \& Mullainathan, 2002, Khanna \& Rivkin, 2001), that is, the expropriation of wealth from minority shareholders and channelling them to the group affiliated under-performing firms (Shleifer \& Vishny, 1997); whereas, contrary to this, there is empirical evidence in favour of family businesses that suggests that such firms do not destroy value on making acquisitions (Caprio, Croc, \& Del Giudice, 2011). Our empirical study sample comprises family owned business-group affiliated firms and stand-alone firms. Thus, in our opinion, undertaking this study has helped us understand the risk-taking behaviour of these firms across different ownership structures, and more importantly has helped us gather empirical evidence related to principal-principal conflicts arising due to the aforementioned ownership structures.

\subsection{Risk Taking Behaviour of the Bidders: Tobit Regression Analysis, and Negative Binomial Regression Analysis}

To understand the risk taking behaviour of bidding firms, we study the changes to firm risk after an acquisition or a merger deal, and if these changes are related to the ownership structure of the bidder. We also look at the past deal activity levels (M\&A activity -total and in unrelated industries) by bidders as another proxy for the risk-taking. Thus, we undertake an inquiry in to the risk-taking behaviour of insider owners which would help us make informed conclusions on the principal-principal dynamics at play in Indian companies.

As discussed in the methodology section, we have employed different proxies of insider ownership and have also considered the squared term of each of the proxies to capture the curvilinear relationship between the risk measure and insider ownership. The market-adjusted measure of risk is a better measure for our regression analysis as compared to the raw measure since the same reflects the firm specific risk.

The models III and IV (in Table 3) report results on regression models that use the overall standard deviation of stock returns as the response variable, whereas, the models I and II report the results on regression models that use the market-adjusted standard deviation of returns as the response variable. Table 4 and 5 report results on the overall M\&A activity and the activity in unrelated industries, respectively; different columns represent models using different insider ownership proxies.

The relationship of the insider ownership with risk is non-linear in nature; the coefficients of the insider ownership proxy term and its squared term (Table 3) suggest that the relationship is positive up to an inflection point, after which the relationship turns negative. Thus, the insider owners undertake risky investments up to a certain level of their holdings, but if their holdings are more than that level, they tend to resort to risk-avoidance (in case of the model I, this turning point is at 45.07 percentage holdings of insider owners (Note 6)). This means that up to a level of insider holdings, principal-principal conflicts are well prevented, but if insiders own stake beyond the majority threshold of close to 50 per cent, we can expect principal-principal conflicts to be present. We observe that the same curvilinear relationship is present in the risk models (Table 3) and also the M\&A activity models (Table 4 and 5). The signs of the coefficients of the insider-ownership proxy and its squared term in the M\&A activity model are exactly opposite to the signs in the risk model. 
Table 3. Bidder risk taking and insider ownership - Tobit regression

\begin{tabular}{|c|c|c|c|c|}
\hline Variables & Market Adj. Risk -Model I & Market Adj. Risk - Model II & Risk-Model III & Risk-Model IV \\
\hline \multirow[t]{2}{*}{ insiderown_proxy6 } & $0.302 * *$ & & 0.3710 & \\
\hline & {$[0.017]$} & & {$[0.241]$} & \\
\hline \multirow[t]{2}{*}{ insiderown_proxy6_sqr } & $-0.335 * *$ & & -0.4230 & \\
\hline & {$[0.046]$} & & [0.328] & \\
\hline \multirow[t]{2}{*}{ insiderown_proxy2 } & & $0.412 * *$ & & 0.6920 \\
\hline & & {$[0.032]$} & & {$[0.121]$} \\
\hline \multirow[t]{2}{*}{ insiderown_proxy2_sqr } & & $-0.380^{*}$ & & -0.6610 \\
\hline & & {$[0.071]$} & & [0.189] \\
\hline \multirow[t]{2}{*}{ Rel_FF } & 0.02610 & 0.02410 & 0.03310 & 0.03050 \\
\hline & {$[0.224]$} & {$[0.266]$} & {$[0.527]$} & {$[0.563]$} \\
\hline \multirow[t]{2}{*}{ Log_deal_size } & $0.0101 * *$ & $0.0112 * *$ & $0.0300 * *$ & $0.0318^{* * *}$ \\
\hline & {$[0.030]$} & {$[0.022]$} & {$[0.011]$} & {$[0.009]$} \\
\hline \multirow[t]{2}{*}{ Acq_percent } & -0.0438 & -0.0469 & -0.0557 & -0.0650 \\
\hline & [0.248] & [0.209] & {$[0.497]$} & [0.429] \\
\hline \multirow[t]{2}{*}{$\mathrm{DE}$} & 0.0246 & 0.0349 & 0.0765 & $0.0876^{*}$ \\
\hline & {$[0.254]$} & {$[0.104]$} & {$[0.120]$} & {$[0.071]$} \\
\hline \multirow[t]{2}{*}{ BG } & $-0.0517 * *$ & $-0.0452^{* *}$ & -0.0852 & -0.0774 \\
\hline & {$[0.018]$} & {$[0.036]$} & [0.104] & {$[0.131]$} \\
\hline \multirow[t]{2}{*}{ Post_1991 } & 0.0364 & $0.0400 *$ & 0.0664 & 0.0684 \\
\hline & [0.136] & {$[0.098]$} & {$[0.244]$} & {$[0.229]$} \\
\hline \multirow[t]{2}{*}{ ConsMatBldg } & 0.0412 & 0.0497 & 0.1090 & 0.1280 \\
\hline & {$[0.213]$} & {$[0.161]$} & {$[0.173]$} & {$[0.110]$} \\
\hline \multirow[t]{2}{*}{ ITConltServ } & 0.0075 & 0.0203 & 0.0329 & 0.0517 \\
\hline & [0.808] & {$[0.521]$} & [0.653] & [0.492] \\
\hline \multirow[t]{2}{*}{ OilGasPow } & -0.0040 & -0.0084 & -0.0195 & -0.0212 \\
\hline & [0.907] & {$[0.814]$} & [0.809] & [0.797] \\
\hline \multirow[t]{2}{*}{ Yr._2009 } & $-0.183^{* * *}$ & $-0.177 * * *$ & $-0.391 * * *$ & $-0.385^{* * *}$ \\
\hline & {$[0.000]$} & {$[0.000]$} & {$[0.000]$} & {$[0.000]$} \\
\hline \multirow[t]{2}{*}{ Yr._2008 } & $0.0805^{* * *}$ & $0.0837 * * *$ & $0.150^{* *}$ & $0.149 * *$ \\
\hline & [0.005] & {$[0.004]$} & {$[0.030]$} & [0.033] \\
\hline \multirow[t]{2}{*}{ Sigma } & $0.152 * * *$ & $0.153 * * *$ & $0.361 * * *$ & $0.361 * * *$ \\
\hline & {$[0.000]$} & {$[0.000]$} & {$[0.000]$} & {$[0.000]$} \\
\hline Pseudo R-Sq & -0.4500 & -0.4430 & 0.2150 & 0.2190 \\
\hline $\mathrm{F}$ & 6.5230 & 6.5160 & 5.3930 & 5.3720 \\
\hline $\mathrm{p}$ & 0.0000 & 0.0000 & 0.0000 & 0.0000 \\
\hline LL & 103.60 & 103.10 & -89.85 & -89.44 \\
\hline
\end{tabular}

Note. This table presents the results of the tobit regression analysis on the risk taking behaviour of insider owners. We have used robust standard errors method while estimating the model: Post - deal Risk over Pre - deal Risk $k_{i}=\alpha+\beta_{1}$ Insider Own $_{i}+$

$\beta_{2}$ Insider Ownrscrease in post vior. ion, atio of director'o use the ratio of and thesis concerning the presence of prinicpal - ter $_{i}^{2} O$ Onsider

$+\beta_{3}$ Rel_fF $_{\mathrm{i}}+\beta_{4}$ Controls $_{\mathrm{i}}$. P-values are in the parentheses. $* \mathrm{p}<0.1$, ** $\mathrm{p}<0.05$, *** $\mathrm{p}<0.01$. Risk is the square root of the ratio of variances after and before the deal. Market adjusted variances is the ratio of the variables after and before the deal adjusted for market wide variance. The total number of observations in the following models is 224 .

In the Anglo-American context, we do find some empirical evidence where insider ownership has non-linear relationship with risk taking (Wright, Kroll, Lado, \& Van Ness, 2002), and also, firm value (McConnel \& Servaes, 1990). This relationship is comprehensible if one considers the fact that a professional manager's employment risk is non-diversifiable. However, the non-linearity observed (between risk/M\&A activity and insider ownership) in the Indian corporate risk-taking is interesting, yet puzzling.

The manager in Indian companies is oftentimes an insider, that is, a promoter. Such an owner-manager, who is an entrepreneur, doesn't face the non-diversifiable employment risk. Although, one could argue that his wealth might be ill-diversified since the substantial part of his wealth is invested in a single firm. However, this argument of 'portfolio concentration' would hold only for the stand alone companies, i.e., the companies that are not affiliated to any business group. Such companies form one-third of our sample. 
Table 4. Bidder M\&A activity and insider ownership - negative binomial regression

\begin{tabular}{|c|c|c|c|c|c|c|}
\hline Variable & $\begin{array}{l}\text { insiderown } \\
\text { proxy1 }\end{array}$ & $\begin{array}{l}\text { insiderown } \\
\text { proxy2 }\end{array}$ & $\begin{array}{l}\text { insiderown } \\
\text { proxy3 }\end{array}$ & $\begin{array}{l}\text { insiderown } \\
\text { proxy4 }\end{array}$ & $\begin{array}{l}\text { insiderown } \\
\text { proxy5 }\end{array}$ & $\begin{array}{l}\text { insiderown } \\
\text { proxy6 }\end{array}$ \\
\hline \multirow[t]{2}{*}{ insiderown } & $-4.383^{* * *}$ & $-3.112 * *$ & $-3.842 * * *$ & $-7.339 * * *$ & $-4.944 * * *$ & -1.1410 \\
\hline & {$[0.003]$} & {$[0.024]$} & {$[0.000]$} & {$[0.000]$} & {$[0.010]$} & {$[0.227]$} \\
\hline \multirow[t]{2}{*}{ insiderown_sqr } & $4.142 * * *$ & $2.994 * *$ & $3.845 * * *$ & $5.342 * * *$ & $3.694^{* *}$ & 1.1710 \\
\hline & {$[0.006]$} & {$[0.037]$} & {$[0.003]$} & {$[0.001]$} & {$[0.037]$} & {$[0.337]$} \\
\hline \multirow[t]{2}{*}{ Rel_FF } & 0.0203 & 0.0044 & 0.0162 & -0.0830 & -0.0281 & -0.0219 \\
\hline & {$[0.905]$} & {$[0.979]$} & [0.924] & {$[0.598]$} & {$[0.865]$} & {$[0.902]$} \\
\hline \multirow[t]{2}{*}{ Log_Assets } & $0.272 * * *$ & $0.282 * * *$ & $0.301 * * *$ & $0.314 * * *$ & $0.296 * * *$ & $0.303 * * *$ \\
\hline & {$[0.000]$} & {$[0.000]$} & {$[0.000]$} & {$[0.000]$} & {$[0.000]$} & {$[0.000]$} \\
\hline \multirow[t]{2}{*}{$\mathrm{DE}$} & 0.0424 & 0.0342 & 0.1920 & 0.0642 & -0.0033 & 0.0818 \\
\hline & {$[0.795]$} & {$[0.832]$} & {$[0.200]$} & {$[0.686]$} & {$[0.984]$} & {$[0.580]$} \\
\hline \multirow[t]{2}{*}{ Post_1991 } & -0.1190 & -0.1290 & -0.0650 & -0.1020 & -0.0994 & -0.1450 \\
\hline & [0.582] & {$[0.548]$} & {$[0.764]$} & [0.632] & {$[0.647]$} & {$[0.508]$} \\
\hline \multirow[t]{2}{*}{ ConsMatBldg } & $0.411 * *$ & $0.521 * * *$ & $0.454 * *$ & $0.767 * * *$ & $0.488^{* *}$ & $0.656^{* * *}$ \\
\hline & {$[0.046]$} & {$[0.009]$} & {$[0.026]$} & {$[0.000]$} & {$[0.014]$} & {$[0.001]$} \\
\hline \multirow[t]{2}{*}{ ITConltServ } & $0.776^{* * * *}$ & $0.854 * * *$ & $0.963 * * *$ & $0.640 * * *$ & $0.711 * * *$ & $0.999 * * *$ \\
\hline & {$[0.003]$} & {$[0.003]$} & {$[0.001]$} & {$[0.005]$} & {$[0.003]$} & {$[0.002]$} \\
\hline \multirow[t]{2}{*}{ OilGasPow } & 0.0161 & 0.0080 & -0.0816 & -0.0133 & 0.0671 & -0.0274 \\
\hline & {$[0.952]$} & [0.976] & {$[0.747]$} & [0.959] & {$[0.792]$} & {$[0.913]$} \\
\hline \multirow[t]{2}{*}{ Yr._2009 } & 0.2960 & 0.2740 & 0.1890 & 0.2460 & 0.2550 & 0.2130 \\
\hline & [0.108] & {$[0.136]$} & {$[0.280]$} & {$[0.175]$} & {$[0.155]$} & {$[0.241]$} \\
\hline \multirow[t]{2}{*}{ Yr._2008 } & 0.1670 & 0.1530 & 0.0958 & 0.1600 & 0.1580 & 0.1020 \\
\hline & {$[0.481]$} & {$[0.521]$} & {$[0.684]$} & {$[0.488]$} & {$[0.504]$} & {$[0.668]$} \\
\hline \multirow[t]{2}{*}{ lnalpha } & $-0.819^{* * *}$ & $-0.733 * *$ & $-0.858 * * *$ & $-0.978 * * *$ & $-0.864 * * *$ & $-0.653 * *$ \\
\hline & {$[0.006]$} & {$[0.011]$} & {$[0.006]$} & {$[0.003]$} & {$[0.005]$} & {$[0.027]$} \\
\hline $\mathrm{N}$ & 204 & 204 & 204 & 204 & 204 & 204 \\
\hline pseudo R-Sq & 0.0930 & 0.0870 & 0.0970 & 0.1030 & 0.0940 & 0.0810 \\
\hline Chi-Sq & 80.870 & 78.090 & 89.790 & 74.010 & 71.680 & 70.440 \\
\hline $\mathrm{p}$ & 0.0000 & 0.0000 & 0.0000 & 0.0000 & 0.0000 & 0.0000 \\
\hline LL & -295.9 & -297.7 & -294.6 & -292.7 & -295.4 & -299.7 \\
\hline
\end{tabular}

Note. The overall M\&A Activity is the dependent variable. This table presents negative binomial regression results for different models with different insider ownership proxies. The Model: M\&A Activity ${ }_{i}=\alpha+\beta_{1}$ Insider Own $_{i}+$

$\beta_{2}$ Insider Ownin post vior. ion, atio of director'o use the ratio of and thesis concerning the presence of prinicpal - ter $_{i}^{2}$ Onsider rscrease

$+\beta_{3}$ Rel_FF $_{\mathrm{i}}+\beta_{4}$ Controls $_{\mathrm{i}}$ (eg. Log Assets, DE, Post_1991, industry effects, year effects.), is estimated using negative binomial regression analysis. P-values are in the parentheses. $* \mathrm{p}<0.1, * * \mathrm{p}<0.05$, *** $\mathrm{p}<0.01$. The regression is estimated with White robust standard errors. The total number of observations in the following modes is 204.

The two-thirds of the firms in our sample are business group affiliated firms, where the promoter-manager has his wealth invested in other group companies as well. Although it is difficult to assess the extent of portfolio diversification thus attained by a promoter manager, the argument of investment concentration weakens. But, there is a possibility that a business group firm is resorting to 'tunnelling' (Morck \& Yeung, 2003). This can be interpreted as an indication that it is likely that the promoter managers are doing more risky projects through the firms in which they have lower cash flow rights compared to the control exhibited. Therefore, it is probable that through the lower layer firms the promoters are taking more risks, tunnelling profits to higher layer firms when profits occur, but when losses are suffered, the lower layer firms absorb them. Since, higher layer firms are the ones where promoter holds higher stake, i.e., higher cash flow rights, these are the firms where risk-aversion is resorted to. Thus, the evidence of risk-reduction and increased diversification ( \& overall M\&A) activity beyond a level of insider ownership around the majority-stake level, points to the astounding fact that these promoter-managers are pursuing goals that are different from the objectives of the minority (dispersed) shareholders.

We observe that deal size has a positive association with the risk measure, suggesting that the principal-principal conflict is more of a concern in the smaller sized deals, but the same is well avoided in the bigger deals. We have employed firm size measured as the log of total assets of bidder in the M\&A activity model (Table 4 and 5), 
since in the context of deal activity, it is a more appropriate control variable than the deal size.

Table 5. Bidder M\&A activity in unrelated industries and insider ownership - negative binomial regression

\begin{tabular}{|c|c|c|c|c|c|c|}
\hline Variable & $\begin{array}{l}\text { insiderown_pro } \\
\text { xy1 }\end{array}$ & $\begin{array}{l}\text { insiderown_pro } \\
\text { xy2 }\end{array}$ & $\begin{array}{l}\text { insiderown_pro } \\
\text { xy3 }\end{array}$ & $\begin{array}{l}\text { insiderown_pro } \\
\text { xy4 }\end{array}$ & $\begin{array}{l}\text { insiderown_prox } \\
\text { y5 }\end{array}$ & $\begin{array}{l}\text { insiderown_prox } \\
\text { y6 }\end{array}$ \\
\hline \multirow[t]{2}{*}{ insiderown } & $-4.408 * *$ & $-3.037 *$ & $-5.259 * * *$ & $-7.361 * *$ & -4.495 & -1.5040 \\
\hline & [0.037] & {$[0.087]$} & {$[0.000]$} & [0.040] & {$[0.136]$} & {$[0.236]$} \\
\hline \multirow[t]{2}{*}{ insiderown_sqr } & $3.943 *$ & 2.783 & $4.695^{* * *}$ & $5.201 *$ & 3.0720 & 1.4640 \\
\hline & [0.064] & {$[0.134]$} & [0.007] & {$[0.061]$} & {$[0.260]$} & [0.333] \\
\hline \multirow[t]{2}{*}{ Rel_FF } & 0.3160 & 0.2780 & 0.3050 & 0.2040 & 0.2640 & 0.2360 \\
\hline & [0.177] & {$[0.235]$} & {$[0.178]$} & {$[0.351]$} & {$[0.241]$} & {$[0.320]$} \\
\hline \multirow[t]{2}{*}{ Log_Assets } & $0.274 * * *$ & $0.285 * * *$ & $0.313 * * *$ & $0.330 * * *$ & $0.306^{* * *}$ & $0.313 * * *$ \\
\hline & [0.001] & [0.001] & {$[0.000]$} & {$[0.000]$} & {$[0.000]$} & {$[0.000]$} \\
\hline \multirow[t]{2}{*}{ DE } & 0.0796 & 0.0804 & 0.3140 & 0.1030 & 0.0236 & 0.1610 \\
\hline & {$[0.727]$} & {$[0.720]$} & [0.107] & [0.639] & [0.918] & {$[0.438]$} \\
\hline \multirow[t]{2}{*}{ Post_1991 } & 0.0902 & 0.0758 & 0.2510 & 0.1010 & 0.1080 & 0.0807 \\
\hline & {$[0.738]$} & {$[0.781]$} & {$[0.360]$} & {$[0.702]$} & [0.688] & {$[0.773]$} \\
\hline \multirow[t]{2}{*}{ ConsMatBldg } & $0.832 * *$ & $0.967 * * *$ & $0.755^{* *}$ & $1.195 * * *$ & $0.907 * * *$ & $1.098 * * *$ \\
\hline & [0.017] & [0.003] & [0.028] & {$[0.000]$} & {$[0.006]$} & [0.001] \\
\hline \multirow[t]{2}{*}{ ITConltServ } & $1.104 * * *$ & $1.209 * * *$ & $1.308 * * *$ & $0.944 * * *$ & $1.049 * * *$ & $1.384 * * *$ \\
\hline & {$[0.000]$} & {$[0.000]$} & {$[0.000]$} & [0.003] & {$[0.000]$} & {$[0.000]$} \\
\hline \multirow[t]{2}{*}{ OilGasPow } & 0.2030 & 0.1890 & 0.1090 & 0.1350 & 0.2230 & 0.1520 \\
\hline & {$[0.575]$} & {$[0.605]$} & {$[0.753]$} & {$[0.715]$} & {$[0.530]$} & {$[0.664]$} \\
\hline \multirow[t]{2}{*}{ Yr._2009 } & $0.453 *$ & 0.4190 & 0.2570 & 0.3740 & 0.4030 & 0.3400 \\
\hline & [0.086] & [0.111] & [0.216] & [0.137] & [0.119] & {$[0.171]$} \\
\hline \multirow[t]{2}{*}{ Yr._2008 } & 0.1910 & 0.1810 & 0.1210 & 0.2150 & 0.1900 & 0.1510 \\
\hline & [0.573] & {$[0.600]$} & {$[0.714]$} & {$[0.532]$} & {$[0.580]$} & {$[0.658]$} \\
\hline \multirow[t]{2}{*}{ Inalpha } & -0.2370 & -0.1680 & -0.4780 & -0.2490 & -0.2510 & -0.0838 \\
\hline & [0.454] & [0.588] & [0.186] & [0.435] & [0.426] & [0.783] \\
\hline $\mathrm{N}$ & 204 & 204 & 204 & 204 & 204 & 204 \\
\hline pseudo R-Sq & 0.1000 & 0.0950 & 0.1210 & 0.1030 & 0.1000 & 0.0920 \\
\hline Chi-Sq & 55.290 & 53.360 & 73.130 & 55.310 & 52.620 & 55.690 \\
\hline $\mathrm{p}$ & 0.0000 & 0.0000 & 0.0000 & 0.0000 & 0.0000 & 0.0000 \\
\hline LL & -203.7 & -204.9 & -199 & -202.9 & -203.8 & -205.6 \\
\hline
\end{tabular}

Note. The M\&A Activity in unrelated industries is the dependent variable. This table presents negative binomial regression results for different models with different insider ownership proxies. The base model: M\&A Activity $y_{\mathrm{i}}=\alpha+\beta_{1}{\text { Insider } 0 w n_{i}}$

$+\beta_{2}$ Insider Ownrscrease in post vior. ion, atio of director'o use the ratio of and thesis concerning the presence of prinicpal $-\operatorname{ter}_{i}^{2} O n s i d e r$

$+\beta_{3} \operatorname{Re}_{\mathrm{i}}+\beta_{4}$ Controls $_{\mathrm{i}}$, is estimated using negative binomial regression. P-values are in the parentheses. * $\mathrm{p}<0.1, * * \mathrm{p}<0.05, * * * \mathrm{p}<0.01$. The regression is estimated with White robust standard errors. The total number of observations in the following modes is 204.

Industry relatedness is a dummy variable employed to separate diversification deals from the deals in the related industries. The proponents of portfolio theory under the aegis of modern financial theory have always considered diversification as a means of reducing unsystematic risk (Wagner \& Lau, 1971, Statman, 1987). However, Lubatkin and O'Neill (1987) have argued and empirically shown that the implications of the portfolio theory fail to hold when corporations diversify. In the words of Lubatkin and O'Neill (1987), 'Diversification will not reduce unsystematic risk because management actions may alter the underlying risk profiles of combining businesses'. They argue that the success of a diversification deal depends largely on a manager's ability to handle the process. Our results on the industry relatedness (Table 3)-show positive relationship between the diversification deals and the risk-taking behaviour of bidders, however, the coefficient is not significant. Moreover, this co-efficient shows the negative relationship with risk measure in the M\&A activity model, yet again it is not significantly different from zero. Hence, with respect to the diversification dummy (industry relatedness), we are unable to support either of the contradictory propositions (Wagner \& Lau, 1971 versus Lubatkin \& O’Neill, 1987).

We observe that higher debt-equity levels lead to greater risk taking (model IV), but the group affiliation makes 
them risk-averse (Table 3). An interesting result to be noted with respect to the control variables is the one with respect to the year dummy for 2009. In 2009, bidders exhibited risk aversion across all deals.

Fink, Grullon, Fink, and Weston (2004) have empirically shown that younger firms are risk takers, but our empirical analysis fails to support this view. In fact, the age of the firm has no significant effect on the risk behaviour of its managers (except in one case, Table 3).

\subsection{Bidder Returns on M\&A Announcements and the Promoter Holdings}

We have presented a summary of significant cumulative abnormal returns (CARs) in Table 6, classified as per promoter holdings. When we segregate the bidder abnormal returns in three categories of promoter holdings, we observe significant positive abnormal returns in different event windows for those bidders who have promoter holdings above 26 per cent (ref. Table 6 , significant mean values are in bold). Twenty-six per cent holding acts as an important cut-off since a shareholder can block special resolutions with shareholdings in excess of twenty-five per cent (as per Companies Act, 1956). Thus, for promoter holdings of twenty-six per cent or more, the deal announcement abnormal returns are persistently positive across different event windows leading up to the day of the announcement.

Table 6. Bidder abnormal returns and promoter holdings

\begin{tabular}{|c|c|c|c|c|c|c|c|c|c|c|c|c|c|c|}
\hline $\begin{array}{c}\text { No. of } \\
\text { Obs. }\end{array}$ & & Day 0 & $\begin{array}{c}\text { Day }-1 \\
\text { to } 0\end{array}$ & $\begin{array}{c}\text { Day }-3 \\
\text { to } 0\end{array}$ & $\begin{array}{c}\text { Day }-5 \\
\text { to } 0\end{array}$ & $\begin{array}{c}\text { Day }-7 \\
\text { to } 0\end{array}$ & $\begin{array}{c}\text { Day } 0 \\
\text { to } 1\end{array}$ & $\begin{array}{c}\text { Day } 0 \text { to } \\
7\end{array}$ & $\begin{array}{c}\text { Day }-1 \\
\text { to } 1\end{array}$ & $\begin{array}{c}\text { Day }-3 \\
\text { to } 3\end{array}$ & $\begin{array}{c}\text { Day -2 } \\
\text { to } 0\end{array}$ & $\begin{array}{c}\text { Day }-2 \\
\text { to } 1\end{array}$ & $\begin{array}{c}\text { Day }-3 \\
\text { to } 1\end{array}$ & $\begin{array}{c}\text { Day }-3 \\
\text { to }-1\end{array}$ \\
\hline \multicolumn{15}{|c|}{ Panel I: Promoter Holdings $<26 \%$} \\
\hline \multirow[t]{2}{*}{28} & Mean & 0.00 & 0.00 & -0.01 & -0.01 & -0.01 & 0.01 & 0.02 & 0.01 & 0.01 & 0.00 & 0.00 & 0.00 & -0.01 \\
\hline & P-value & 0.69 & 0.92 & 0.64 & 0.52 & 0.54 & 0.36 & 0.27 & 0.64 & 0.63 & 0.70 & 0.80 & 0.95 & 0.34 \\
\hline \multicolumn{15}{|c|}{ Panel II: Promoter holdings >= $26 \%$ but less than $50 \%$} \\
\hline \multirow[t]{2}{*}{112} & Mean & 0.00 & 0.01 & 0.01 & 0.01 & 0.02 & 0.00 & -0.01 & 0.01 & 0.01 & 0.01 & 0.01 & 0.01 & 0.01 \\
\hline & P-value & 0.14 & 0.04 & 0.03 & 0.04 & 0.07 & 0.65 & 0.06 & 0.20 & 0.43 & 0.08 & 0.28 & 0.11 & 0.10 \\
\hline \multicolumn{15}{|c|}{ Panel III: Promoter Holdings $>=50 \%$} \\
\hline \multirow[t]{2}{*}{137} & Mean & 0.01 & 0.02 & 0.02 & 0.02 & 0.01 & 0.01 & 0.01 & 0.02 & 0.01 & 0.02 & 0.02 & 0.02 & 0.01 \\
\hline & P-value & 0.00 & 0.00 & 0.00 & 0.02 & 0.08 & 0.01 & 0.43 & 0.01 & 0.04 & 0.00 & 0.01 & 0.01 & 0.11 \\
\hline
\end{tabular}

Note. This table presents a summary of bidder abnormal returns, i.e., cumulative abnormal returns over different event windows. For example, event window 'Day -1 to 0 ' presents cumulative abnormal returns over two days - a day before the event and the event day. The segregation is based on the significant ownership thresholds, beyond which a shareholder can either block special resolutions (in case of ownership of 26 per cent or more), or has majority holdings (in case of 50 per cent or more). No. of obs. are the number of deals that satisfied the cut-off levels of promoter holdings. Mean -is the mean value of the cumulative abnormal returns over a given event window of all the observations.

\section{Conclusion}

In this study, we look at the agency theory relevant to emerging economies, which is called as the principal-principal agency conflict in the popular academic literature. There is extant empirical evidence pointing to opportunism undertaken by managers in the widely held Anglo-American companies. The primary driver for managers to resort to risk aversion is their employment risk which is non-diversifiable.

We undertake an inquiry into the risk-taking behaviour of promoter managers in an emerging economy, which presents us with a distinctive business setting with characteristics like high ownership concentration and complex structures -in the form of business groups with cross holdings and pyramidal arrangements. This context posits the possibility of the existence of the principal-principal agency between the dispersed shareholders and the majority shareholders.

On conducting an analysis on the risk-taking behaviour of bidders, we observe a curvilinear relationship between the insider ownership and the idiosyncratic risk of bidders. We observe a similar curvilinear relationship between high ownership concentration and the diversification activity (as well as overall M\&A activity) undertaken by promoter-managers. The direct relationship between risk-taking behaviour and ownership concentration, and the indirect relation between diversification activity and insider ownership, is consistent with the theoretical predictions. However, the non-linearity in these relationships suggest that insider managers resort to risk aversion beyond the majority (or the near-majority) level of ownership.

The above evidence on risk-taking behaviour is quite intriguing, since the 'non-diversification of employment risk' argument doesn't hold for business-group firms which comprise two-thirds of our sample. But, the 
business-group affiliated firms have a tendency to resort to tunnelling, and that could be distorting their risk-taking behaviour. The promoter-manager could be using lower layers firms for undertaking risky projects, and cushioning the higher level firms (where higher stakes are held) from the downsides of risks. The cash-flow rights are much lower compared to the control held (through the pyramid) in the lower layer firms, and therefore, a promoter manager can do risky investments, tunnel the gains out, and distance himself from the burden of losses when suffered.

The above evidence suggests that principal-principal conflicts are likely to exist in Indian firms, especially in bidding firms with very high ownership concentration. However, on studying the abnormal returns on deal-announcements, we observe that when the Indian bidders with high ownership concentration announce M\&A deals, they create value. Therefore, even if the deals undertaken by Indian acquirers reduce post-deal risk, such deals do not destroy shareholder wealth. Thus, the subsequent result on positive abnormal returns on deal announcements weakens the possibility of the presence of principal-principal conflicts that adversely affect shareholder wealth.

\section{Acknowledgements}

The authors would like to thank Prof. Purusottam Sen and Prof. Manisha Chakrabarty, and the conference participants and the discussants at the 6th IIM Ahmedabad Doctoral Colloquium 2013 and at the 51st Annual Eastern Finance Association Meeting 2015, for their valuable suggestions, feedback and comments.

\section{References}

Agrawal, A., \& Mandelker, G. N. (1987). Managerial incentives and corporate investment and financing decisions. The Journal of Finance, 42(4), 823-837. http://dx.doi.org/10.1111/j.1540-6261.1987.tb03914.x

Amihud, Y., \& Lev, B. (1981). Risk reduction as a managerial motive for conglomerate mergers. The Bell Journal of Economics, 605-617. http://dx.doi.org/10.2307/3003575

Bertrand, M., Mehta, P., \& Mullainathan, S. (2002). Ferreting out tunneling: An application to Indian business groups. Quarterly Journal of Economics, 117, 121-48. http://dx.doi.org/10.1162/003355302753399463

Bettis, R. A. (1983). Modern financial theory, corporate strategy and public policy: Three conundrums. Academy of Management Review, 8(3), 406-415. http://dx.doi.org/10.5465/AMR.1983.4284379

Brown, S. J., \& Warner, J. B. (1985). Using daily stock returns: The case of event studies. Journal of Financial Economics, 14(1), 3-31. http://dx.doi.org/10.1016/0304-405X(85)90042-X

Caprio, L., Croci, E., \& Del Giudice, A. (2011). Ownership structure, family control, and acquisition decisions. Journal of Corporate Finance, 17(5), 1636-1657. http://dx.doi.org/10.1016/j.jcorpfin.2011.09.008

Chen, Y. Y., \& Young, M. N. (2010). Cross-border mergers and acquisitions by Chinese listed companies: A principal-principal perspective. Asia Pacific Journal of Management, 27(3), 523-539. http://dx.doi.org/10.1007/s10490-009-9150-7

Cornett, M. M., Hovakimian, G., Palia, D., \& Tehranian, H. (2003). The impact of the manager-shareholder conflict on acquiring bank returns. Journal of Banking \& Finance, 27(1), 103-131. http://dx.doi.org/10.1016/S0378-4266(01)00210-2

Dharwadkar, B., George, G., \& Brandes, P. (2000). Privatization in emerging economies: An agency theory perspective. Academy of Management Review, 25(3), 650-669. http://dx.doi.org/10.5465/AMR.2000.3363533

Fink, J., Grullon, G., Fink, K., \& Weston, J. (2004). Firm age and fluctuations in idiosyncratic risk. Available at SSRN 891173.

Frye, M. B. (2004). Equity - based compensation for employees: Firm performance and determinants. Journal of Financial Research, 27(1), 31-54. http://dx.doi.org/10.1111/j.1475-6803.2004.00076.x

Guay, W. R. (1999). The sensitivity of CEO wealth to equity risk: An analysis of the magnitude and determinants. Journal of Financial Economics, 53(1), 43-71. http://dx.doi.org/10.1016/S0304-405X(99)00016-1

Huchet, J., \& Ruet, J. (2006). Globalisation and Opening Markets in Developing Countries and Impact on National Firms and Public Governance: The Case of India. Project Report, Project co-finance by the European Union under the EU-India Small Projects Facility Programme.

Jensen, M. C. (1986). Agency cost of free cash flow, corporate finance, and takeovers. American Economic Review, 76(2), 323-329. 
Jensen, M. C. (1993). The modern industrial revolution, exit, and the failure of internal control systems. Journal of Finance, 48(3), 831-880. http://dx.doi.org/10.1111/j.1540-6261.1993.tb04022.x

Jensen, M. C., \& Meckling, W. H. (1976). Theory of the firm: Managerial behavior, agency costs and ownership $\begin{array}{lllll}\text { structure. Journal of } & \text { Financial }\end{array}$ http://dx.doi.org/10.1016/0304-405X(76)90026-X

Khanna, T., \& Palepu, K. (2000a). Emerging market business groups, foreign intermediaries, and corporate governance. In Morck, R. (Ed.), Concentrated Corporate Ownership (pp. 265-92). Chicago, IL: University of Chicago Press.

Khanna, T., \& Palepu, K. (2000b). The future of business groups in emerging markets: Long-run evidence from Chile. Academy of Management journal, 43(3), 268-285. http://dx.doi.org/10.2307/1556395

Khanna, T., \& Rivkin, J. W. (2001). Estimating the performance effects of business groups in emerging markets. $\begin{array}{llll}\text { Strategic Management } \quad \text { Journal, } & \text { 45-74. }\end{array}$ http://dx.doi.org/10.1002/1097-0266(200101)22:1<45::AID-SMJ147>3.0.CO;2-F

Laeven, L., \& Levine, R. (2007). Is there a diversification discount in financial conglomerates? Journal of Financial Economics, 85(2), 331-367. http://dx.doi.org/10.1016/j.jfineco.2005.06.001

Lane, P. J., Cannella, A. A., \& Lubatkin, M. H. (1998). Agency problems as antecedents to unrelated mergers and diversification: Amihud and Lev reconsidered. Strategic Management Journal, 19(6), 555-578. http://dx.doi.org/10.1002/(SICI)1097-0266(199806)19:6<555::AID-SMJ955>3.0.CO;2-Y

Lewellen, W., Loderer, C., \& Rosenfeld, A. (1985). Merger decisions and executive stock ownership in acquiring firms. Journal of Accounting and Economics, 7(1), 209-231. http://dx.doi.org/10.1016/0165-4101(85)90038-2

Lewellen, W., Loderer, C., \& Rosenfeld, A. (1989). Mergers, executive risk reduction, and stockholder wealth. Journal of Financial and Quantitative Analysis, 24(4), 459-472. http://dx.doi.org/10.2307/2330979

Lloyd, W. P., Modani, N. K., \& Hand, J. H. (1987). The effect of the degree of ownership control on firm diversification, market value, and merger activity. Journal of Business Research, 15(4), 303-312. http://dx.doi.org/10.1016/0148-2963(87)90002-6

López de Silanes, F., La Porta, R., Shleifer, A., \& Vishny, R. (1998). Law and finance. Journal of Political Economy, 106, 1113-1155. http://dx.doi.org/10.3386/w5661

Lubatkin, M., \& O'Neill, H. M. (1987). Merger strategies and capital market risk. Academy of Management Journal, 30(4), 665-684. http://dx.doi.org/10.2307/256154

MacKinlay, A. C. (1997). Event studies in economics and finance. Journal of Economic Literature, 35(1), 13-39.

Martin, J. D., \& Sayrak, A. (2003). Corporate diversification and shareholder value: A survey of recent literature. Journal of Corporate Finance, 9(1), 37-57. http://dx.doi.org/10.1016/S0929-1199(01)00053-0

McConnell, J. J., \& Servaes, H. (1990). Additional evidence on equity ownership and corporate value. Journal of Financial Economics, 27(2), 595-612. http://dx.doi.org/10.1016/0304-405X(90)90069-C

Minnick, K., Unal, H., \& Yang, L. (2011). Pay for performance? CEO compensation and acquirer returns in BHCs. Review of Financial Studies, 24(2), 439-472. http://dx.doi.org/10.1093/rfs/hhq107

Morck, R., \& Yeung, B. (2003). Agency problems in large family business groups. Entrepreneurship Theory and Practice, 27(4), 367-382. http://dx.doi.org/10.1111/1540-8520.t01-1-00015

Morck, R., Shleifer, A., \& Vishny, R. W. (1990). Do managerial objectives drive bad acquisitions? The Journal of Finance, 45(1), 31-48. http://dx.doi.org/10.1111/j.1540-6261.1990.tb05079.x

Morck, R., Wolfenzon, D., \& Yeung, B. (2005). Corporate Governance, Economic Entrenchment, and Growth. Journal of Economic Literature, 63, 655-720. http://dx.doi.org/10.3386/w10692

Porta, R., Lopez - de - Silanes, F., \& Shleifer, A. (1999). Corporate ownership around the world. The Journal of Finance, 54(2), 471-517. http://dx.doi.org/10.1111/0022-1082.00115

Rajan, R., Servaes, H., \& Zingales, L. (2000). The cost of diversity: The diversification discount and inefficient investment. The Journal of Finance, 55(1), 35-80. http://dx.doi.org/10.1111/0022-1082.00200

Roll, R. (1986). The hubris hypothesis of corporate takeovers. Journal of Business, 59(2), 197-216. http://dx.doi.org/10.1086/296325 
Rose, N. L., \& Shepard, A. (1997). Firm Diversification and CEO Compensation: Managerial Ability or Executive Entrenchment? The Rand Journal of Economics, 28(3), 489-514. http://dx.doi.org/10.3386/w4723

Saunders, A., Strock, E., \& Travlos, N. G. (1990). Ownership structure, deregulation, and bank risk taking. the Journal of Finance, 45(2), 643-654. http://dx.doi.org/10.1111/j.1540-6261.1990.tb03709.x

Sesil, J. C., Kroumova, M. K., Kruse, D. L., \& Blasi, J. R. (2007). Broad-based employee stock options in the US-company performance and characteristics. Management Revue, 5-22.

Shekhar, C., \& Torbey, V. (2005). Takeovers, Ownership, and Shareholder Wealth-The Australian Evidence. Review of Accounting and Finance, 4(3), 101-120. http://dx.doi.org/10.1108/eb043433

Shleifer, A., \& Vishny, R. W. (1989). Management entrenchment: The case of manager-specific investments. Journal of Financial Economics, 25(1), 123-139. http://dx.doi.org/10.1016/0304-405X(89)90099-8

Shleifer, A., \& Vishny, R. W. (1997). A survey of corporate governance. The Journal of Finance, 52(2), 737-783. http://dx.doi.org/10.1111/j.1540-6261.1997.tb04820.x

Statman, M. (1987). How many stocks make a diversified portfolio? Journal of Financial and Quantitative Analysis, 22(3), 353-363. http://dx.doi.org/10.2307/2330969

Villalonga, B. (2004). Diversification discount or premium? New evidence from the business information $\begin{array}{llll}\text { tracking } & \text { Theries. Tournal of }\end{array}$ http://dx.doi.org/10.1111/j.1540-6261.2004.00640.x

Wagner, W. H., \& Lau, S. C. (1971). The effect of diversification on risk. Financial Analysts Journal, 27(6), 48-53. http://dx.doi.org/10.2469/faj.v27.n6.48

Williams, M. A., \& Rao, R. P. (2006). CEO stock options and equity risk incentives. Journal of Business Finance \& Accounting, 33(1-2), 26-44. http://dx.doi.org/10.1111/j.1468-5957.2006.01357.x

Wright, P., Kroll, M., Lado, A., \& Van Ness, B. (2002). The structure of ownership and corporate acquisition strategies. Strategic Management Journal, 23(1), 41-53. http://dx.doi.org/10.1002/smj.208

Young, M. N., Peng, M. W., Ahlstrom, D., Bruton, G. D., \& Jiang, Y. (2008). Corporate governance in emerging economies: A review of the principal-principal perspective. Journal of Management Studies, 45(1), 196-220. http://dx.doi.org/10.1111/j.1467-6486.2007.00752.x

\section{Notes}

Note 1. Pyramidal structure enables greater control in the hands of the insiders, over and above their cash flow rights (Porta et al., 1998).

Note 2. Promoter(s) (and the people acting in concert, i.e., friends, relatives, etc.) is a business promoter(s) and a shareholder(s) with substantial shareholding, and is more than likely the founder(s) of the enterprise. She has significant control over the affairs of the firm and therefore, she could be called the insider-manager or promoter-manager.

Note 3. For more details on this statistical method please refer: Soderbom, Mans and Teal, Francis. 2008. "Corner solutions, Censoring and Truncation." Available on: http://www.economics.ox.ac.uk/Intra/Grad/MSc/2007-08/QuantMethods/Lecture\%20Notes_FJT/HT_Lectures_h andouts/lec3ht_08_censoring.pdf. Accessed on $17^{\text {th }}$ October, 2012.

Note 4. Source: Prowess, CMIE. http://prowess.cmie.com/, accessed on $17^{\text {th }}$ October, 2012.

Note 5. CMIE is Centre for Monitoring Indian Economy. It provides company financial performance data for Indian companies through the Prowess Database.

Note 6. Since in this sample the turning point is close to the majority-holding threshold of 50 per cent, we can safely interpret this turning point to be at the majority threshold. 


\section{Appendix}

Appendix A. Variable definitions

\begin{tabular}{|c|c|}
\hline Acq_percent & The percentage of stake acquired in a deal \\
\hline $\mathrm{BG}$ & $\begin{array}{l}\text { A dummy variable to identify business group affiliated bidders; it assumes value } 1 \text { if an acquirer is a business } \\
\text { group affiliated firm, otherwise it takes value } 0\end{array}$ \\
\hline Cross Border & A dummy variable, which assumes value 1 if a deal is a cross border deal, otherwise it takes value 0. \\
\hline ConsMatBldg & $\begin{array}{l}\text { A dummy variable, which assumes value } 1 \text { if an acquirer's industry is construction material, } \\
\text { building/construction and engineering }\end{array}$ \\
\hline $\mathrm{DE}$ & The debt-equity ratio of an acquirer \\
\hline Debt Cost & $\begin{array}{l}\text { The cost of debt is measured as the ratio of interest expense and the average borrowings in the quarter before } \\
\text { deal announcement. }\end{array}$ \\
\hline Debt Cost Dummy & $\begin{array}{l}\text { A dummy variable, which assumes value } 1 \text { if the acquirer's cost of debt before the deal announcement is more } \\
\text { than the median cost of debt, } 0 \text { otherwise. The cost of debt is measured as the ratio of interest expense and the } \\
\text { average borrowings in the quarter before deal announcement. }\end{array}$ \\
\hline FIN & $\begin{array}{l}\text { The method of financing for a deal, defined as a binary variable, assuming the value } 1 \text { if it is a stock offer, } 0 \text { if } \\
\text { it is a cash offer }\end{array}$ \\
\hline Insider Own or insiderown & The proxy for promoter holdings expressed as percentage of equity holdings by promoters. \\
\hline Insiderown_sqr & $\begin{array}{l}\text { The square of promoter holdings. If the proxy used for insider ownership is 'Insiderown_proxy1', then this } \\
\text { term is denoted as 'insiderown_proxy1_sqr'. }\end{array}$ \\
\hline Insiderown_Proxy1 & The total promoter holdings, including holdings by the persons acting in concert \\
\hline Insiderown_Proxy2 & The sum of holdings by all the Promoters, Indian as well as foreign \\
\hline Insiderown_Proxy3 & The total of Indian Promoters and the persons acting in concert \\
\hline Insiderown_Proxy4 & $\begin{array}{l}\text { The holdings by promoters as well as non-promoter institutions like mutual funds, UTI (Unit Trust of India), } \\
\text { insurance companies, etc. }\end{array}$ \\
\hline Insiderown_Proxy5 & The sum of the holdings of Promoters and non-promoter FIIs \\
\hline Insiderown_Proxy6 & The sum of holdings by Indian promoters \\
\hline ITConltSftw & A dummy variable, which assumes value 1 if an acquirer's industry is IT consulting and services, and software \\
\hline Log_Assets & The log of bidder's total assets \\
\hline Log Deal Size & The $\log$ of the transaction value \\
\hline $\begin{array}{l}\text { Market Adjusted Risk or } \\
\text { Mkt. Adj. Var Ratio }\end{array}$ & $\begin{array}{l}\text { The market adjusted standard deviation of stock returns are used to calculate this measure. This measure is a } \\
\text { ratio of the post deal market adjusted standard deviation of returns over the pre-deal market adjusted standard } \\
\text { deviation of returns. This variable is defined in section } 3 \text {. }\end{array}$ \\
\hline Merger & A dummy variable, which takes value 1 if the form of a deal is merger, otherwise it takes value 0 \\
\hline Non-Prom Hold & Percentage of outstanding shares held by non-promoters in a bidding company \\
\hline OilGasPow & $\begin{array}{l}\text { A dummy variable, which assumes value } 1 \text { if an acquirer's industry is oil and gas, petrochemicals, power, and } \\
\text { other energy }\end{array}$ \\
\hline Percent Acq26 & $\begin{array}{l}\text { A dummy variable based on the percentage of stake acquired in a deal. It assumes value } 1 \text { if the per cent } \\
\text { acquired exceeds } 26 \text { per cent, otherwise it takes value zero }\end{array}$ \\
\hline Percent Owned & The percentage of the target's outstanding shares held by an acquirer after the bid \\
\hline Premium & The ratio of the offer price to the target's share price (four weeks prior to the deal announcement). \\
\hline Prom Hold & $\begin{array}{l}\text { Promoter holdings of an acquirer before deal announcement, expressed as a percentage of total outstanding } \\
\text { shares. }\end{array}$ \\
\hline Prom Hold Acq50 & $\begin{array}{l}\text { The percentage of promoter holdings for a deal if the percentage of stake acquired is } 50 \text { per cent or more. This } \\
\text { variable assumes value } 0 \text { for the observations where the percentage of stake acquired is less than } 50 \text {. }\end{array}$ \\
\hline Post 1991 & Companies that were established post 1991. This measure is provided by the CMIE's Prowess Database. \\
\hline Recession Yr. Dummy & A dummy variable to identify recession years $-2007,2008$ and 2009 \\
\hline Rel_FF & $\begin{array}{l}\text { The industry relatedness dummy variable for a deal, assuming value } 0 \text { if the acquirer and the target are in the } \\
\text { same industry, } 1 \text { otherwise. For determining whether a merger is happening in the same industry we have } \\
\text { considered the } 49 \text { industry classification provided by Fama-French. }\end{array}$ \\
\hline Rel Size & $\begin{array}{l}\text { The relative size of a transaction, measured as the ratio of the value of the transaction over the market value of } \\
\text { its acquirer. }\end{array}$ \\
\hline Risk & $\begin{array}{l}\text { The raw standard deviation of stock returns are used to calculate this measure. This measure is the ratio of the } \\
\text { post deal standard deviation of returns over the pre-deal standard deviation of returns. }\end{array}$ \\
\hline Sqrt DE & The square root of the acquirer's debt-equity ratio before deal announcement \\
\hline Var Ratio & Post-deal risk over pre-deal risk as defined in section 3 . The variance in this ratio is not market-adjusted. \\
\hline Yr_2008 & A dummy variable that assumes value 1 if the deal was announced in 2008 \\
\hline Yr_2009 & A dummy variable that assumes value 1 if the deal was announced in 2009 \\
\hline
\end{tabular}




\section{Copyrights}

Copyright for this article is retained by the author(s), with first publication rights granted to the journal.

This is an open-access article distributed under the terms and conditions of the Creative Commons Attribution license (http://creativecommons.org/licenses/by/3.0/). 